\title{
Minireview
}

\section{Nitric Oxide as Key Mediator of Neuron-to-Neuron and Endothelia-to-Glia Communication Involved in the Neuroendocrine Control of Reproduction}

\author{
Nicole Bellefontaine ${ }^{a-c}$ Naresh Kumar Hanchate ${ }^{a-c}$ Jyoti Parkash ${ }^{a-c}$ \\ Céline Campagne $^{a-c}$ Sandrine de Seranno ${ }^{a-c}$ Jérôme Clasadonte ${ }^{a-c}$ \\ Xavier d'Anglemont de Tassigny ${ }^{a-c}$ Vincent Prevot $^{\mathrm{a}-\mathrm{d}}$ \\ anserm, Jean-Pierre Aubert Research Center, Development and Plasticity of the Postnatal Brain, U837, \\ bUniversité Lille Nord de France, ' ${ }^{\mathrm{b}}$ USL, School of Medicine, and ${ }^{\mathrm{d}} \mathrm{CHRU}$ Lille, Department of Neurosurgery, \\ Hôpital Roger Salengro, Lille, France
}

\section{Key Words}

Luteinizing hormone-releasing hormone $\cdot$ Gaseous

transmitter $\cdot$ Endothelial nitric oxide synthase .

Neurosecretion $\cdot$ Neuronal-glial plasticity $\cdot$ Reproduction

\begin{abstract}
Nitric oxide (NO) is a peculiar chemical transmitter that freely diffuses through aqueous and lipid environments and plays a role in major aspects of brain function. Within the hypothalamus, NO exerts critical effects upon the gonadotropin-releasing hormone ( $\mathrm{GnRH}$ ) network to maintain fertility. Here, we review recent evidence that NO regulates major aspects of the $\mathrm{GnRH}$ neuron physiology. Far more active than once thought, NO powerfully controls GnRH neuronal activity, $\mathrm{GnRH}$ release and structural plasticity at the neurohemal junction. In the preoptic region, neuronal nitric oxide synthase (nNOS) activity is tightly regulated by estrogens and is found to be maximal at the proestrus stage. Natural fluctuations of estrogens control both the differential coupling of this $\mathrm{Ca}^{2+}$-activated enzyme to glutamate $\mathrm{N}$-methyl$\mathrm{D}$-aspartic acid receptor channels and phosphorylation-mediated nNOS activation. Furthermore, NO endogenously produced by neurons expressing nNOS acutely and directly suppresses spontaneous firing in GnRH neurons, which sug-
\end{abstract}

gests that neuronal NO may serve as a synchronizing switch within the preoptic region. At the median eminence, $\mathrm{NO}$ is spontaneously released from an endothelial source and follows a pulsatile and cyclic pattern of secretion. Importantly, $\mathrm{GnRH}$ release appears to be causally related to endothelial NO release. NO is also highly involved in mediating the dialogue set in motion between vascular endothelial cells and tanycytes that control the direct access of $\mathrm{GnRH}$ neurons to the pituitary portal blood during the estrous cycle. Altogether, these data raise the intriguing possibility that the neuroendocrine brain uses NO to coordinate both GnRH neuronal activity and $\mathrm{GnRH}$ release at key stages of reproductive physiology.

Copyright $\odot 2011$ S. Karger AG, Basel

\section{Introduction}

As the final common pathway for the central control of reproduction, gonadotropin-releasing hormone $(\mathrm{GnRH})$ neurons are regulated by multiple neuronal networks and interactions with non-neuronal cells that intermingle in a complex array of transsynaptic inputs [1$3]$ and paracrine communication $[4,5]$, subjected to the modulatory influence of gonadal steroids that prompts

\section{KARGER}

Fax +4161306 1234

E-Mail karger@karger.ch

www.karger.com
(C) 2011 S. Karger AG, Basel

0028-3835/11/0932-0074\$38.00/0

Accessible online at:

www.karger.com/nen
Vincent Prevot

Inserm U837, Bâtiment Biserte

Place de Verdun

FR-59045 Lille Cedex (France)

Tel. +33 3206220 64, E-Mail vincent.prevot@inserm.fr 
both chemical $[6,7]$ and structural plasticity $[8,9]$. In rodents, the cell bodies of GnRH neuroendocrine neurons are mostly located in the preoptic region. Neuroendocrine GnRH neurons send their neuronal processes to the median eminence of the hypothalamus, where $\mathrm{GnRH}$ is released into the pituitary portal vessels. Upon reaching the anterior pituitary, GnRH elicits the secretion of luteinizing hormone (LH) and follicle-stimulating hormone (FSH), which in turn stimulate gametogenesis and gonadal hormone secretion.

The present article will review recent findings that have unveiled some of the regulatory mechanisms involving neuronal and non-neuronal sources of nitric oxide (NO) in the control of GnRH neuron function. NO is indeed a very dynamic chemical transmitter that is well positioned to play a crucial role in regulating both the activity and secretion of GnRH neurons.

\section{Nitric Oxide: Production, Synthesizing Enzymes and Downstream Targets}

Originally described as the endothelial-derived relaxing factor [10-12], NO is a highly labile gaseous messenger molecule that is generated as a by-product from the conversion of L-arginine to L-citrulline. The formation of NO requires the enzyme nitric oxide synthase (NOS), in which there are three isoforms: two constitutive (i) neural-type NOS I (nNOS) and (ii) endothelial-type III (eNOS), and one inducible NOS II (iNOS) isoform [13]. All three isoforms generate NO by oxidizing a guanidino nitrogen group from L-arginine utilizing nicotinaminde adenine dinucleotide phosphate (NADPH) as an electron donor $[13,14]$.

Mapping of the constitutive forms of NOS, through specific antibodies and NADPH-diaphorase histochemistry, show both nNOS and eNOS are expressed in the brain [15-21]. While eNOS is mainly found in the vasculature in both the periphery and the brain, it has also been documented in neurons of the hippocampus $[17,19]$. The nNOS isoform is located in several populations of neuronal cells in the cerebellum, olfactory bulb, hippocampus, and is also highly expressed within neurons of the hypothalamus $[15,18,22,23]$. While the activity of the inducible isoform is $\mathrm{Ca}^{2+}$ independent [24], the constitutive NOS isoforms activities are dependent on both $\mathrm{Ca}^{2+}$ and calmodulin $[12,14,25,26]$. In the central nervous system, it has been well described that the activation of N-methylD-aspartic acid (NMDA) receptors (NMDA-R) by glutamate provides the necessary increase in intracellular cal- cium required for activation of nNOS, whereas other pathways that increase intracellular $\mathrm{Ca}^{2+}$ are much less efficient in eliciting nNOS activity [12, 14, 27]. In endothelial cells, the abundance of the principal resident coat protein of caveolae, caveolin-1, appears to be an important regulator of eNOS activity [28]. Caveolin-1 interacts with eNOS [29] and leads to its inhibition in a reversible process modulated by $\mathrm{Ca}^{2+}$-calmodulin [30]. Both nNOS and eNOS must be bound to the membrane, and require further phosphorylation of 1412 and 1179 serine residues, respectively, through the PI3K/AKT signaling pathway, for full activation [31,32]. The eNOS isoform is a dually acylated peripheral membrane protein that targets into the Golgi region and plasma membrane of endothelial cells and is, itself, compartmentalized to the membrane [31]. This stands in contrast to the nNOS isoform that requires a scaffolding protein to couple itself to the membrane [33-35]. Recent studies suggested that nNOS might also be subjected to repressive sets of posttranslational modifications in vivo, such as phosphorylation at the Ser847 site by calcium-calmodulin-dependent kinase II $[32,36,37]$. Thus, the regulation of the activity of nNOS appears to be mainly dependent on three factors: sufficient $\mathrm{Ca}^{2+}$ influx through activation of NMDA-R, subcellular localization via a scaffolding protein, and phosphorylation of specific serine residues. Regarding eNOS, the most important mechanism for sustaining its activity is phosphorylation on serine-1179, enabling the enzyme to function at resting $\mathrm{Ca}^{2+}$ cytosolic concentrations [for review, see 38] and interaction of eNOS with caveolin is used to prevent inadequate NO production under basal conditions [39].

Since NO is not stored in vesicles, following its synthesis, NO diffuses across the biological membranes to produce its effect. However, the ability of NO to exert an action is delineated by its half-life and the proximity of NOcontaining cells to their target, which must be within 200 $\mu \mathrm{m}$ [40-42]. This distance indeed corresponds to the physiological sphere of influence from a single-point source of NO that emits for 1-10 s [41]. In the brain, NO is typically considered to be a retrograde neurotransmitter (i.e. increasing release of other neurotransmitters, such as GABA and glutamate from presynaptic sites); however, it also acts at postsynaptic sites [for review, see 43]. The most well-documented target or 'receptor' of NO is the soluble guanylate cyclase (sGC), in which the activation by NO results in formation of cyclic GMP (cGMP) to mediate intracellular effects $[44,45]$. NO binds to the ferrous heme of sGC with high affinity to change the conformation of sGC and therefore dramatically increases its 
catalytic activity [46]. Following treatment of NO, the synthesis of prostaglandins (PGs) has also been documented [47]. The conversion of arachidonic acid to PGs requires cyclooxygenase (COX), thus COX may also be considered as a downstream target of NO. Similar to the sGC enzyme, COX contains an iron-heme group suggesting a direct interaction between $\mathrm{NO}$ and COX $[48,49]$. Indeed, it was demonstrated that COX is a direct target for NO, and the increase of PGs was independent of cGMP $[48,49]$. Of note, the formation of $\mathrm{PGE}_{2}$ by COX appears to play an important role in the neuroendocrine control of the reproductive axis $[50,51]$.

\section{Neuronal Nitric Oxide Modulates GnRH Neuronal Activity and Secretion during the Ovarian Cycle}

Since the early 1990s, NO has been known to be a regulator of LH secretion [for review, see 1, 52-54]. Indeed, several pharmacological studies suggested $\mathrm{NO}$ as a key modulator of GnRH secretion $[55,56]$, and a contributor in the onset of the preovulatory surge of GnRH/LH [5761]. Intracerebroventricular injection of NOS antisense oligodeoxynucleotides was shown to block the LH surge in steroid-primed ovariectomized rats [60], whereas intracerebral infusion of $\mathrm{N}^{\mathrm{G}}$-nitro-L-arginine methyl ester (L-NAME, a NOS inhibitor) either within the preoptic region (fig. 1) or the median eminence caused a marked disruption of rat estrous cyclicity [62, 63]. Intriguingly, in mutant mice, the first targeted disruption of the nNOS gene in exon 2 did not markedly alter fertility [64]. However, these mutant mice retained residual nNOS activity [64]. In contrast, deletion of exon 6, which harbors the catalytic domain of nNOS, was shown to cause hypogonadotropic hypogonadism and infertility in mutant mice [65].

\section{Neuronal NO Exerts an Acute Postsynaptic Action on} GnRH Neurons

Early studies using immortalized GnRH cell lines suggested that NO acts directly at the level of the cell body to either inhibit [66] or stimulate GnRH release and synchronize pulsatile GnRH secretion [55, 66-68]. In contrast to these in vitro models where $\mathrm{GnRH}$-secreting cells express NO-producing enzymes [67, 69, 70], consistent mapping of the nNOS isoform within the hypothalamus demonstrated that GnRH perikarya are surrounded by nNOS neurons, but do not express nNOS themselves [22, 71-73] (fig. 1a). Due to the scattered nature of GnRH neurons across the preoptic region, the putative action of $\mathrm{NO}$ at the level of the $\mathrm{GnRH}$ cell body was difficult to assess. With the advancement in genetic techniques and the engineering of mice expressing green fluorescent protein (GFP) in GnRH neurons [74-76], GnRH neuronal activ-
Fig. 1. Within the preoptic region, NO release modulates $\mathrm{GnRH}$ neuronal activity and is required for estrous cyclicity. a The relationship of NO-producing neurons stained with NADPH-diaphorase to GnRH neurons in GnRH-GFP transgenic mice. NOS and neuronal NADPH diaphorase are identical in brain and peripheral tissues [20,21]. Arrows show close relationships between NADPHdiaphorase-containing neurons (dark precipitate) and GnRH-GFP neurons (green). Scale bar: $40 \mu \mathrm{m}$. b Whole-cell patch-clamp recordings show that L-arginine ( $\mathrm{L}-\mathrm{Arg}$, the precursor of NO) alters spontaneous firing in $\mathrm{GnRH}$ neurons (top panel). Application of L-NAME, a NOS inhibitor, prevented L-Arg-mediated inhibition of spontaneous discharges in L-Arg-responsive GnRH neurons (bottom panel) [73]. c Microscopic visualization of nNOS catalytic activity using immunofluorescence to localize L-citrulline, a byproduct of NO synthesis. Representative illustration of nNOS-expressing neurons (red) and L-citrulline detection (green) by fluorescent immunocytochemistry in coronal brain sections from diestrous (Di 16h) and proestrous (Pro 16h) rats. V3 = Third ventricle; oc $=$ optic chiasm. Right panels: high magnifications of the areas delineated by rectangles. Arrowheads indicate double-labeled neurons expressing nNOS and L-citrulline. Arrows indicate nNOS single-labeled neurons. Low magnification scale bar: $210 \mu \mathrm{m}$; high magnification scale bar: $60 \mu \mathrm{m}$. d Top panel: representative profiles of spontaneous $\mathrm{NO}$ secretion from preoptic region explants at two different stages of the estrous cycle in the female rat. Differential current measured by the self-referencing probe, converted to flux (vertical axis), increased after the addition of single preoptic explants in survival medium at the time indicated by arrow. NO effluxes recorded from each explant during the 90 -min data acquisition phase were averaged and plotted on the bar graph. Comparisons between stages of the estrous cycle indicated that preoptic explants produced significantly more $\mathrm{NO}$ on the afternoon of proestrus than on the afternoon of diestrus $\left({ }^{*} p=0.014\right)$. Bottom panel: representative response of a proestrous rat preoptic explant to vehicle (veh, arrowhead) or to $1 \mathrm{mM}$ L-NAME (arrow). Comparisons between treatments indicated that L-NAME, but not vehicle, significantly reduced NO production by the preoptic region during proestrus $\left({ }^{*} \mathrm{p}=0.017\right)$. The transient drops in current upon substance application (arrowhead, arrow) are artifacts. e Disruption of estrous cyclicity in young adult rats by the pharmacological blockade of NO synthesis targeted to the preoptic region of the hypothalamus. L-NAME ( $5 \mathrm{mM})$ or vehicle $(\mathrm{NaCl} 0.9 \%)$ delivered via a stereotaxically implanted stainless steel cannula connected to a subcutaneously placed osmotic pump delivering its content at a rate of $0.5 \mu \mathrm{l} / \mathrm{h}$ for 7 days. Infusion starts at $\mathrm{P} 0$ (arrow pointing up) and ends 7 days later (arrow pointing down), when the pump content is exhausted. Di = Diestrus; Pro = proestrus; Es = estrus [adapted from 62, 73, with permission]. 
ity can now be readily examined in brain slice preparations. Using patch-clamp recordings from GnRH-GFP mouse brain slices, our laboratory has provided the first electrophysiological evidence that NO is a direct modulator of native GnRH neuron excitability [73]. Both endogenous and exogenous sources of $\mathrm{NO}$ were shown to cause acute inhibition of spontaneous firing in $\mathrm{GnRH}$ neurons [73] (fig. 1b). Importantly, L-arginine (the natural sub- strate for NOS-mediated NO production) inhibitory effects on GnRH bursting activity were abolished when brain slices were incubated with L-NAME, a broadspectrum NOS inhibitor (fig. 1b), or (4S)-N-(4-amino5 -[aminoakyl] aminopentyl)- $\mathrm{N}^{\prime}$-nitroguanidines (AAANG), a selective inhibitor of nNOS $[73,77]$. The ability of NO to inhibit GnRH neuron firing and induce $\mathrm{GnRH}$ neuron hyperpolarization is retained during syn-

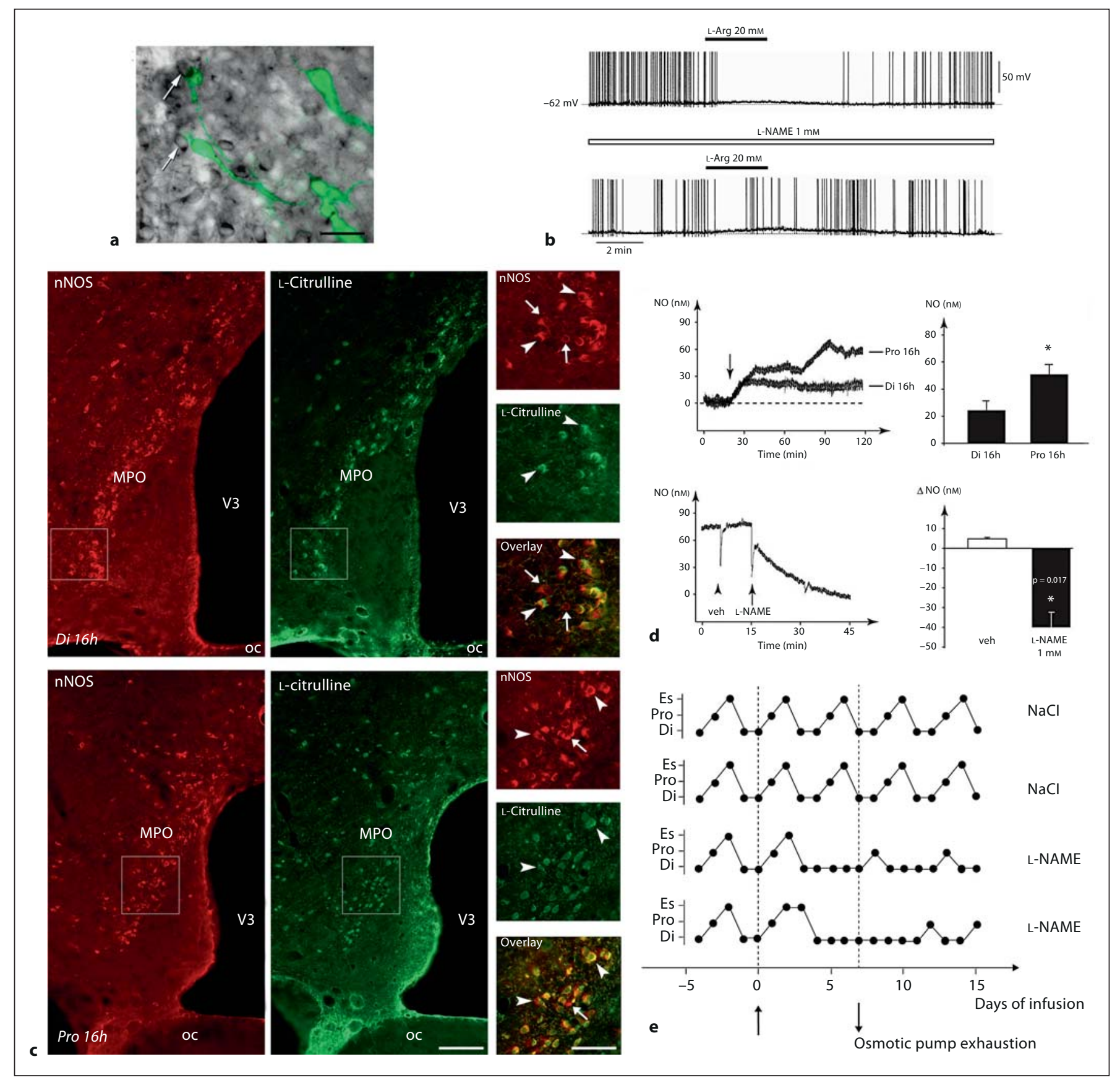


aptic uncoupling with a medium containing low- $\mathrm{Ca}^{2+}$ and high- $\mathrm{Mg}^{2+}$ to block $\mathrm{Ca}^{2+}$-dependent presynaptic release, and TTX to block voltage-gated sodium channels. This indicates a direct action of NO at a postsynaptic site to change membrane properties in GnRH neurons [73]. Notably, NO appears to require the sGC-cGMP signaling cascade to modulate neuronal excitability in $\mathrm{GnRH}$ neurons. The presence of a sGC antagonist blocked the inhibition of firing promoted by $\mathrm{NO}$ in $\mathrm{GnRH}$ neurons, while an exogenous cGMP analog mimicked the action of NO [73]. By revealing that $\mathrm{NO}$ is a direct modulator of $\mathrm{GnRH}$ neuronal activity, these data introduce the intriguing possibility that the neuronal release of this highly diffusible gaseous neurotransmitter with a short half-life $(<1 \mathrm{~s})$ may be a key mechanism used by the neuroendocrine brain to both modulate bursting firing patterns, and set into phase the bursting activity of GnRH neurons (fig. 1). Because NO production is key to the occurrence of the preovulatory surge of $\mathrm{GnRH}$ [57-61], it is tempting to speculate that NO may serve as a transitory switch between pulse and peak release of $\mathrm{GnRH}$ in proestrus [7880]. Such a switch could be operated by estrogens during the onset of the preovulatory surge [7] and might require the intervenience of additional neuronal circuits, including kisspetin neurons, as discussed bellow.

\section{Estrogens Modulate Neuronal Nitric Oxide Signaling within the Preoptic Region}

Should NO act to synchronize GnRH neuronal cell activity, a critical question remains: Does the release of $\mathrm{NO} / \mathrm{nNOS}$ activity fluctuate in parallel with gonadal hormones across the estrous cycle? Amperometric measurements performed with a NO-specific probe on rat hypothalamus explants showed that NO production varies during the estrous cycle in the preoptic region and that the amplitude of NO effluxes is significantly higher in proestrus (when estrogen levels are highest) than in diestrus [62] (fig. 1d). Concurrently, the microscopic visualization of NOS catalytic activity using immunohistofluorescence to localize L-citrulline, which is formed stoichiometrically with NO [12] showed that the proportion of nNOS neurons producing NO is significantly higher in proestrus than in diestrus II in the preoptic region (average citrulline/nNOS co-expression, Di 16h $78 \pm 5 \%$, Pro $16 \mathrm{~h} 90 \pm 2 \%$; test, $\mathrm{p}=0.049, \mathrm{n}=6$ per stage of the estrous cycle; fig. 1c) [62].

Intriguingly, in contrast with previous studies suggesting that estrogen could modulate hypothalamic nNOS gene expression [58, 81-84], these changes in NO secretion seen during the estrous cycle are not associated with changes in nNOS protein synthesis but rather with changes in nNOS activity $[62,85]$. Estradiol induces the formation of a NMDA-R-nNOS complex in neurons of the preoptic region [62, 85], thus enhancing NO secretion [86] by coupling nNOS to its main stimulatory calcium influx pathway $[12,14]$ (box). This differential coupling of nNOS with NMDA-Rs during the estrous cycle was shown to involve the scaffolding protein postsynaptic density-95 (PSD-95) [62, 86] (fig. 2) and to require estrogen receptor (ER) activity [86] (box). PSD-95 knockdown via the administration of antisense PSD-95 oligodeoxynucleotides strikingly impaired ovarian cyclicity [62] (fig. 2) and nNOS activity in preoptic neurons both in vitro [86] and in vivo [62]. Importantly, inhibition of estradiol-induced NO release by selective NMDA-R blockers demonstrated that estrogen actually promotes the coupling of glutamatergic fluxes for NO production in preoptic neurons [86]. The evidence that NO-producing neurons in the hypothalamus could be targets of glutamate was demonstrated by neuroanatomical studies showing that virtually all preoptic nNOS neurons, which are also known to express ER- $\alpha[87,88]$, express NMDA receptors $[62,71]$. Interestingly, other studies have shown that most NMDA-R-expressing neurons of the preoptic region also contain ER- $\alpha$ [89], which can be visualized in cell nuclei, perikaryal cytoplasm, and dendrites [90, 91]. In parallel to promoting changes in protein-protein interactions, natural fluctuations of estrogens across the ovarian cycle were also recently shown to regulate the state of activation of nNOS through changes in nNOS stimulatory phosphorylation levels in the preoptic region [85]. Phosphorylation of nNOS at Ser1412 was shown to be maximal on the afternoon of proestrus and this phosphorylation-activated nNOS isoform was seen to physically interact with the PSD-95/NMDA-R complex at the plasma membrane [85] (box). Correspondingly, in physiologically relevant environmental conditions associated with low LH release, such as fasting, the phosphorylation of nNOS is decreased [92]. In vitro experiments performed in primary culture of hypothalamic neurons showed that estradiol promotes phosphorylation of nNOS at Ser1412 via a Src/PI3K/Aktdependent pathway [93]. The above findings suggest a direct action of estrogens on nNOS neurons of the preoptic region. This would couple NO production to glutamate fluxes that exert a well-known stimulatory influence on GnRH secretion during their positive feedback on the hypothalamus $[94,95]$. The resulting production of NO may then act on GnRH neuron cell bodies to synchronize their activity and adjust their firing behavior in a meaningful manner to enable peak release of $\mathrm{GnRH}$. 


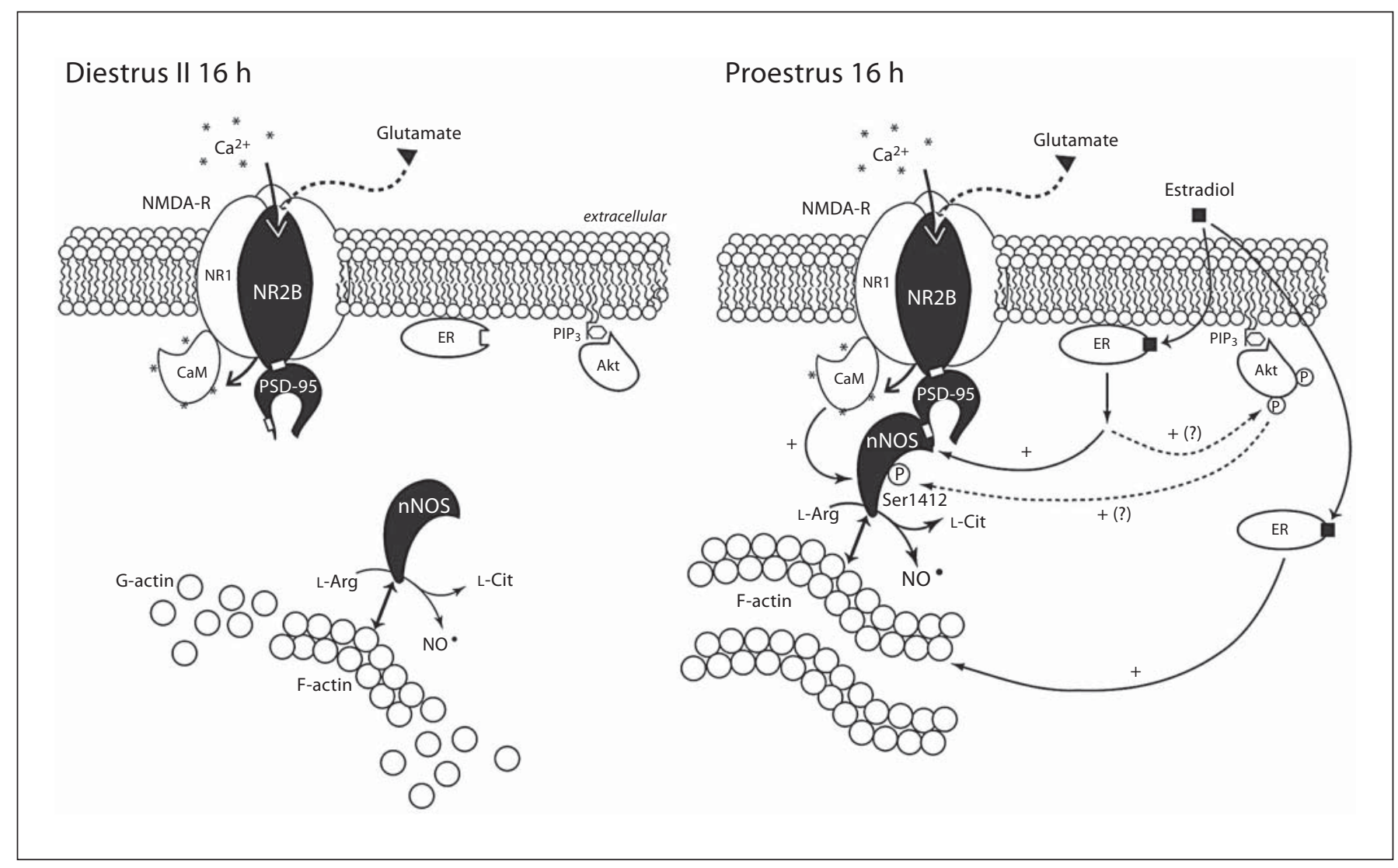

Box: Schematic representation of the possible estradiol-mediated changes in protein-protein interactions involved in the control of nNOS activity in the preoptic region of the hypothalamus during the ovarian cycle. nNOS activity is primarily regulated by increases in the local intracellular $\left[\mathrm{Ca}^{2+}\right]\left(^{*}\right)$, which activates nNOS through calmodulin $(\mathrm{CaM})$ binding [14]. The physical interaction of nNOS with NMDA-Rs involves the PSD-95 scaffolding protein and the assembly of a ternary complex [34]. Only $\mathrm{Ca}^{2+}$ influx through the NMDA-R promotes an efficient NO production [12, 14]. In parallel, nNOS is also subjected to posttranscriptional modifications (such as phoshorylation) that modulates its catalytic activity [32, 142-144]. Natural fluctuations of estrogen levels across the ovarian cycle, i.e. low in diestrus and high in proestrus, regulate the activation state of nNOS by modulating its coupling with NR2B-containing NMDA-Rs by the PSD-95 scaffolding protein. In turn, this regulation, that could be mediated by estrogen-dependent ER activation [86], results in the phosphorylation

\section{A Role for NO in Kisspeptin Signaling?}

ER $\alpha$-expressing neurons of the anteroventral periventricular nucleus (AVPV), the median preoptic nucleus $(\mathrm{MnPO})$ and the periventral hypothalamic nucleus $(\mathrm{Pe})$, containing a significant subset of hypothalamic nNOS neurons $[23,62,73,84]$, are critical for estrogen-positive feedback to the GnRH neurons $[96,97]$. While NO trans- of nNOS, an effect known to increase nNOS enzymatic activity $[31,32]$. Estrogens may induce nNOS phosphorylation through the activation of the Src/PI3K/Akt pathway [93]. The mechanism by which estrogen promotes nNOS anchoring to the PSD-95/ NMDA-R complex remains unknown. Estrogen exhibits widespread effects throughout the brain and its actions are intensively investigated, but very few studies have considered the relationship between estrogen and PSD-95. In vitro estrogen upregulates the synthesis of PSD-95 via the Akt/protein kinase B pathway [145] and alters the shape of hippocampal dendritic spine [146] where PSD-95 is present in high amounts. Perhaps the nNOS association with PSD-95 is enhanced at synaptic sites in response to dynamic events at the postsynaptic density. One plausible mechanism for this would be that the estrogen signalling mediates the coalescence of cytoskeleton-tethered nNOS [147] to PSD-95 through spine formation, which would require remodeling of the actin cytoskeleton [148] [adapted from 85, with permission]. 

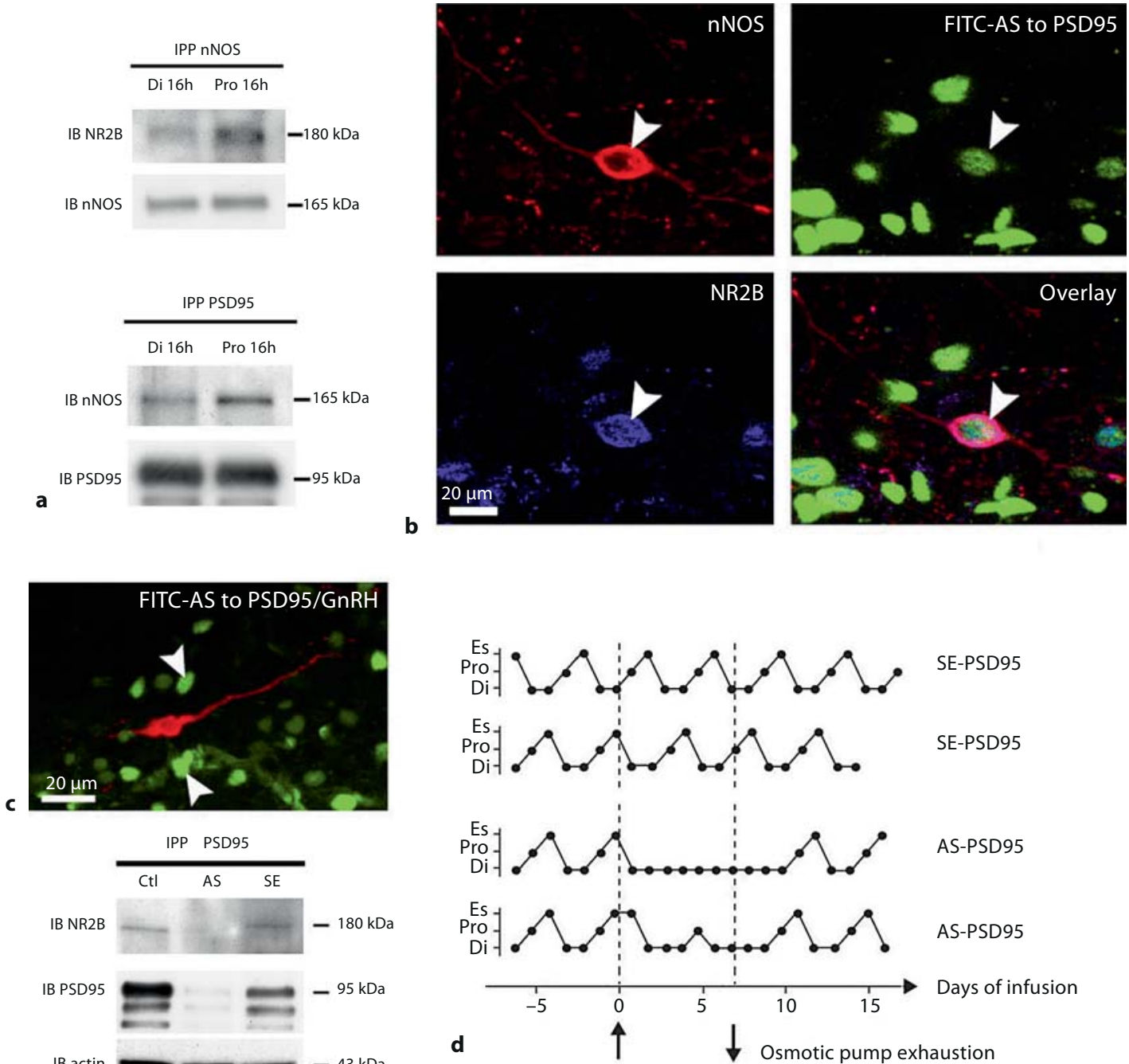

Fig. 2. The estrous cycle promotes changes in nNOS coupling to glutamate NMDA-R channels and requires the scaffolding protein PSD-95 in the preoptic region. a Co-immunoprecipitation experiments show that NMDA-R NR2B subunit is highly physically associated with nNOS on the afternoon of proestrus (top panel). The bottom panel shows that differential NR2B/nNOScomplex formation involves changes in physical association of PSD-95/nNOS. b-d Central administration of an antisense PSD95 ODN results in estrous cycle disruption in sexually mature rats. b Confocal microscopy images showing that AS-PSD-95 FITC-coupled ODNs directly target NR2B-expressing nNOS neurons (arrowhead) in vivo when stereotaxically infused into the preoptic region. c Confocal microscopy images illustrating a GnRH-immunoreactive neuron (red) surrounded by cells that incorporated AS-PSD-95 FITC-coupled ODNs (green, arrowheads) in the preoptic region. d Representative estrous cycle profiles showing disruption of estrous cyclicity in young adult rats by the infusion of AS-PSD-95 into the hypothalamic preoptic region. Infusion starts at day 0 (arrow pointing up), and ends 7 days later (arrow pointing down), when the pump content is exhausted. $\mathrm{Di}=$ Diestrus; Pro = proestrus; Es = estrus; SE-PSD-95, sense PSD-95-ODNs. e Selective decrease of PSD-95 expression and its association with NR2B in hypothalamic neurons treated with the antisense oligodeoxynucleotide to PSD-95 (PSD-95 ODN) in vitro. Cells were treated with the antisense ODN $(5 \mu \mathrm{M})$ or a sense sequence for 7 days, then protein extracts were immunoprecipitated with antibodies to PSD-95 and sequentially immunoblotted with NR2B and PSD-95 antibodies. The supernatant resulting from immunoprecipitation was subjected to straight Western blotting for actin [adapted from 62, with permission]. 

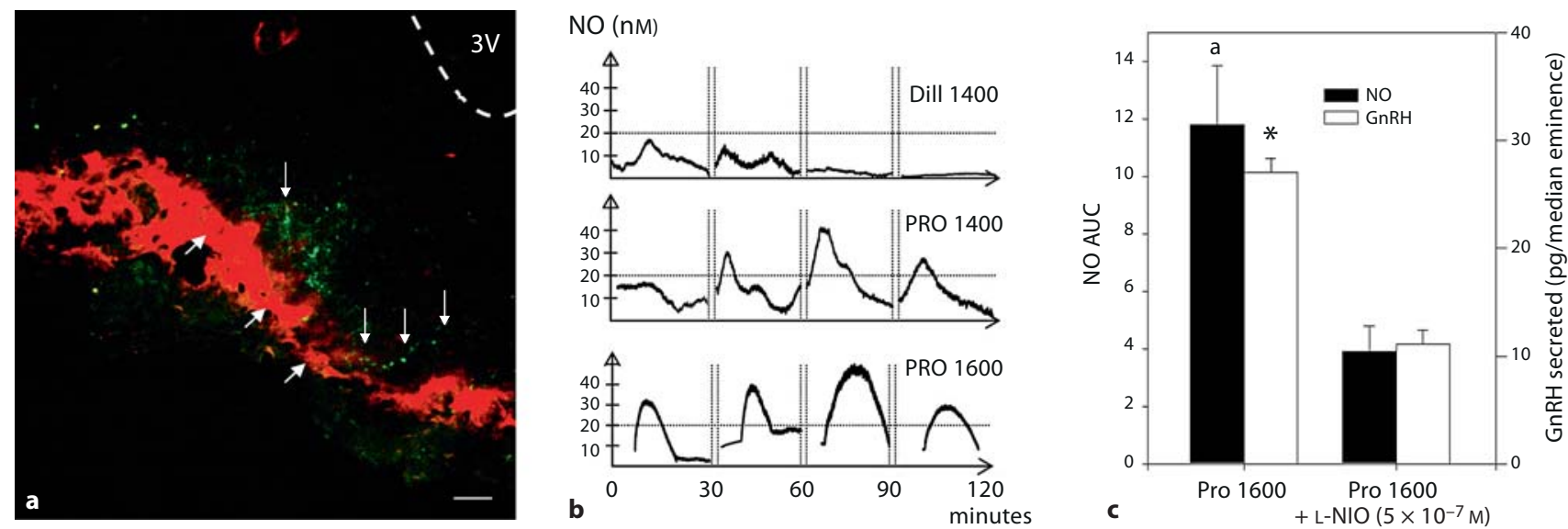

Fig. 3. In the median eminence of the hypothalamus, endothelial NO secretion may represent one of the synchronizing cues that by coordinating $\mathrm{GnRH}$ release from $\mathrm{GnRH}$ neuroendocrine terminals that are distributed over $2 \mathrm{~mm}$ within the median eminence allows the occurrence of functionally meaningful episodes of GnRH secretion. a Photomicrograph showing GnRH axonal fibers in the external zone of the median eminence (green fluorescence, arrows) in close apposition to eNOS-immunoreactive portal vasculature (red fluorescence, arrowheads). $3 \mathrm{~V}=$ Third ven-

tion [101-105], recent studies demonstrated that intracerebroventricular injection of NMDA, the selective agonist of glutamate NMDA-Rs, induces nNOS neuron activation and LH release in kisspeptin and kisspeptin receptor knockout mice [106]. These findings suggest that glutamate-stimulated $\mathrm{NO}$ production triggers $\mathrm{GnRH}$ neuronal function in a kisspeptin-independent manner. Interestingly, preliminary data show that kisspeptin- and nNOS-containing neurons morphologically interact in the preoptic region [107]. Thus, it is possible that in addition to act both directly on GnRH neurons and via actions on synaptic afferents [108-110], kisspetin neurons may also talk to nNOS neurons and promote NO production that could serve as an intermediary synchronizing 'switch'. This interesting possibility awaits further study.

\section{Endothelial Nitric Oxide Controls GnRH Release at the Neurohemal Junction}

Neuroendocrine GnRH neurons project to the median eminence of the hypothalamus, where they release their decapeptide into the pituitary portal blood vessels for delivery to the anterior pituitary. The median eminence, tricle. The dotted lines outline the third ventricle. Scale bar: 75 $\mu \mathrm{m}$. b Real-time amperometric measurement of spontaneous NO release from median eminence explants at different stages of the rat estrous cycle. DiII = Diestrus II; PRO = proestrus; E = estrus. c On the afternoon of proestrus, the preovulatory $\mathrm{GnRH} / \mathrm{NO}$ release is blocked with L-NIO, an NOS inhibitor selective for eNOS at $0.5 \mu \mathrm{M} .{ }^{*}$ and ${ }^{\mathrm{a}}=$ Significantly different from treated samples, $\mathrm{p}=0.05$. AUC $=$ Area under the curve during a $30-\mathrm{min}$ period [adapted from 54, 114, with permission].

which lies ventrally to the third ventricle in the tuberal region of the hypothalamus, is increasingly recognized as a key site for $\mathrm{GnRH}$ release regulation [5, 9, 111, 112]. Modulation of $\mathrm{GnRH}$ release by $\mathrm{NO}$ within the median eminence was suggested by early studies performed by McCann and colleagues. They demonstrated that NO stimulates release of $\mathrm{GnRH}$ from explants of the medial basal hypothalamus, containing the median eminence [for review, see 53]. Neuroanatomical studies showed that the two types of constitutive NOS were expressed within the median eminence $[18,22,54,113]$. Notably, nNOS expression is restricted to axons of the magnocellular neurons that travel in the internal zone to end in the neurohypophysis, and are distinctly segregated from $\mathrm{GnRH}$ axon terminals [22]. In contrast, eNOS is abundantly expressed by vascular endothelial cells in the external zone lying only a few micrometers away from GnRH nerve terminals [54] (fig. 3a). The source of median eminence NO production involved in the regulation of $\mathrm{GnRH}$ release was identified with the development of amperometric methods, allowing for real-time measurements of NO release [114]. These studies demonstrated that $\mathrm{NO}$ was spontaneously released in a pulsatile manner, and that NO secretion was positively correlated to $\mathrm{GnRH}$ release 
[114] (fig. 3b). Notably, the efflux of NO from the median eminence occurs at pulse rate $(32 \pm 1 \mathrm{~min})$ [114] strikingly similar to the pulse rate of $\mathrm{GnRH}$ secretion from rat median eminence explants (33 \pm 8 min) $[115,116]$. Critically, the treatment of a selective eNOS inhibitor $\left(\mathrm{N}^{5}\right.$ (1-iminoethyl)-L-ornithine dihydrochloride (L-NIO)) to median eminence explants obtained from rats on the afternoon of proestrus blunted both $\mathrm{NO}$ and $\mathrm{GnRH}$ release [114], thus demonstrating these two events were causally linked (fig. 3c). These results together with the selective expression of eNOS in the capillary zone of the median eminence (fig. 3a) suggest that the major source of NO regulating $\mathrm{GnRH}$ release within the median eminence during the estrous cycle is endothelial in origin. The key role of median eminence NO in the control of estrous cyclicity was demonstrated by the chronic infusion of L-NAME, a NO synthesis blocker, within the median eminence that reversibly altered the ovarian cycle [63].

\section{Estrogens Modulate Endothelial Nitric Oxide}

Signaling within the Median Eminence

Amperometric analysis showed a variation of the amplitude of median eminence NO across the estrous cycle reaching maximal values on the day of proestrus [114] alongside the increase in $\mathrm{GnRH}$ pulse amplitude known to occur in vivo [80]. Estrous cycle effects on $\mathrm{NO}$ effluxes are mimicked by estradiol treatment in ovariectomized rats [114], suggesting that estrogens drive the increase in the amplitude of NO release at the onset of the preovulatory surge. This long-term stimulatory effect of estrogens appears to involve upregulation of Nos2 gene expression $[117,118]$ and downregulation of caveolin-1 protein synthesis [117], which is a well-known specific endogenous inhibitor of eNOS activity $[119,120]$. Interestingly, estrogens were also shown to have an acute stimulatory effect on median eminence $\mathrm{NO} / \mathrm{GnRH}$ release that might be mediated through an ER-dependent non-genomic signaling pathway regulating eNOS activity [121] by promoting changes in intracellular calcium concentrations in endothelial cells [122].

Endothelial Nitric Oxide May Be a Key Mediator of

Neuronal-Glial Plasticity in the GnRH System during the Estrous Cycle

Within the median eminence, $\mathrm{GnRH}$ axon terminals are intimately associated with cell processes belonging to specialized unciliated ependymoglial cells named tanycytes. Tanycyte cell bodies are tied at their apex by tight junctions [123] and line the floor of the third ventricle. They send long fine processes that eventually contact the floor of the brain via end-feet processes where the pituitary portal vessels reside [124]. These tanycytic end-feet processes have been found not only to wrap the GnRH nerve terminals [125-128], possibly providing a diffusion barrier, but also display a high degree of structural plasticity across the estrous cycle in rats $[129,130]$ and seasonal breeding periods in quails [131]. During the estrous cycle, under basal conditions, e.g. in diestrus, the GnRH nerve terminals are completely enclosed by tanycyte endfeet $[129,130]$. In proestrus, following activation of the reproductive axis, presumably by increasing levels of gonadal steroids [125], end-feet processes are retracted, thus allowing GnRH neurons to directly contact the pericapillary space [130]. These data argue for the importance of tanycyte structural rearrangement in delivering peak levels of $\mathrm{GnRH}$ to the pituitary during the preovulatory surge. The intriguing possibility that endothelial NO could be involved, at least in part, in the control of this plastic phenomenon arises from recent studies using immunopanning methods to purify vascular endothelial cells of the median eminence and culture them with isolated tanycytes $[63,132]$. These studies showed that median eminence endothelial cells were capable of promoting acute actin cytoskeleton reorganization in tanycytes (within $30 \mathrm{~min}$ of co-culture) via the release of NO. Inhibition of NO production by preincubating vascular endothelial cells with L-NAME [63], or infection of the median eminence endothelial cells with an adenovirus expressing a dominant negative form of eNOS (DN-eNOS) [132], prevented endothelial cell-promoted actin cytoskeleton remodeling in tanycytes. Conversely, tanycyte treatment with sodium nitroprusside (SNP), a NO donor, at concentrations releasing physiological doses of $\mathrm{NO}$, mimicked the co-culture effects $[63,132]$. Downstream effectors of endothelial NO-mediated plasticity in tanycytes were shown to be both sGC- and COX-dependent [63]. Notably, estradiol was shown to enhance endothelial-to-tanycyte communication by causing endothelial cell-promoted acute retraction of tanycytic processes in an endothelial NO-dependent manner [132]. These effects are indeed abolished when the DN-eNOS is expressed in endothelial cells (fig. 4a) and partially mimicked when endogenous production of NO is triggered by L-arginine in nonestradiol-treated co-cultures [132]. Moreover, treatment of diestrous median eminence explants with L-arginine also caused tanycytic processes surrounding GnRH nerve terminals to undergo acute retraction (within 30 $\mathrm{min}$ ), enabling GnRH neurons to form direct neurohemal junctions, as demonstrated by electron microscopy [63] (fig. 4b). 

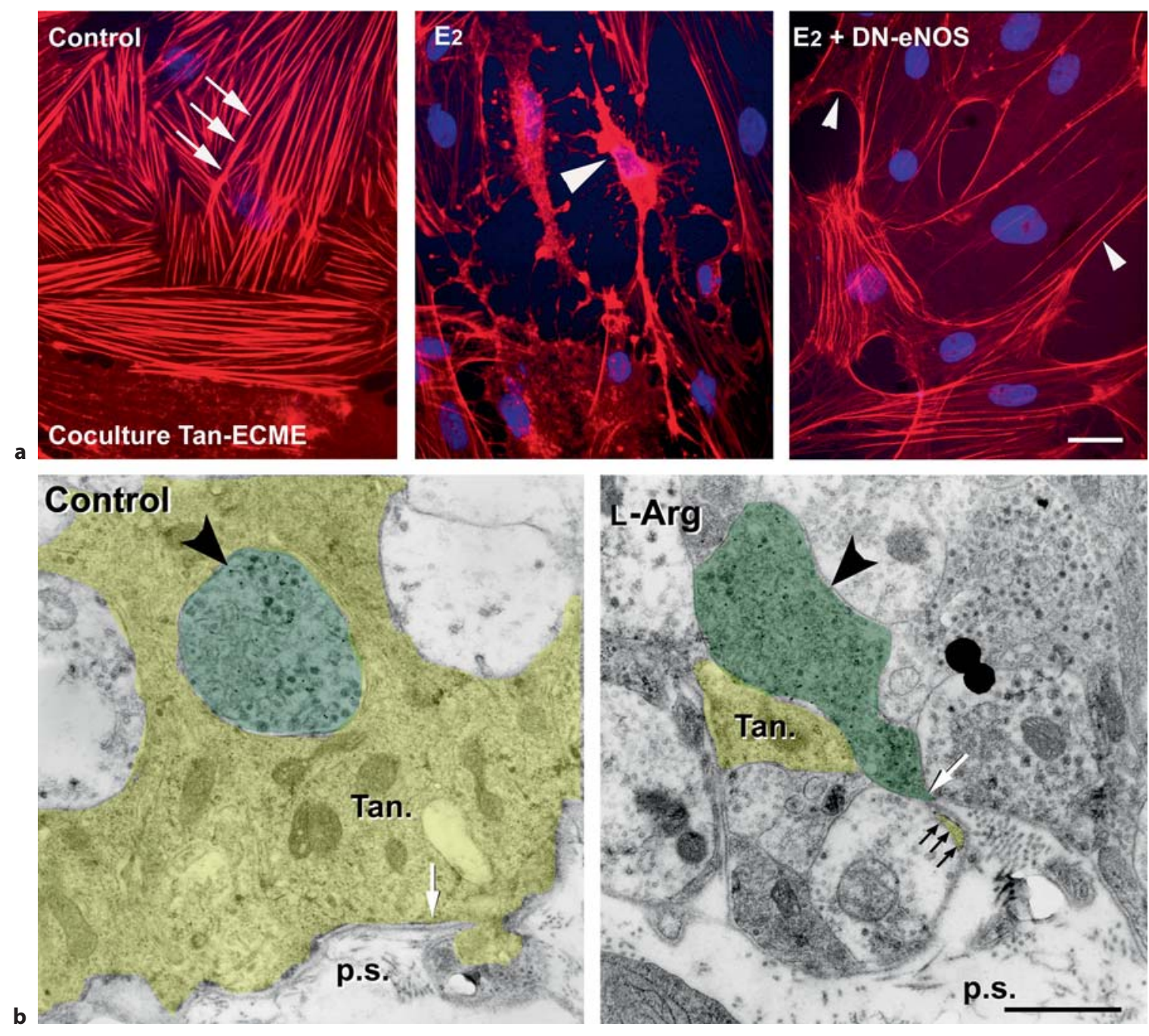

Fig. 4. NO mediates the vascular endothelial cell-induced plasticity in tanycytes of the median eminence. a eNOS activity is required for endothelial cell to promote actin cytoskeleton remodeling and cell plasticity in tanycytes. Tanycytes (Tan) cultured with endothelial cells of the median eminence (ECME) for $30 \mathrm{~min}$ exhibit bundles of actin filaments forming parallel stress fibers (arrows, control panel) running throughout the length of the cells, but do not exhibit cortical actin (little arrowhead). Estradiol treatment $(5 \mathrm{nM}, 48 \mathrm{~h}$ ) promotes dramatic cytoplasm and process retraction in tanycytes co-cultured with ECME for 30 min (long arrowhead, $E_{2}$ panel). Infection of endothelial cells with an adenoviral vector expressing DN-eNOS, which abolishes eNOS activity by heterodimerizing with native eNOS [149], prevents them from promoting such plastic changes in tanycytes cultured in the presence of estradiol $\left(\mathrm{E}_{2}+\mathrm{DN}-\mathrm{eNOS}\right.$ panel). Tanycytes co-cultured with DN-eNOS-expressing ECMEs displayed cortical actin (arrowheads). Scale bar: $10 \mu \mathrm{m}$. b Activation of en- dogenous NO secretion in median eminence explants induces ultrastructural changes that allows GnRH nerve terminals (green, big arrowhead) to form direct neurovascular junctions in isolated median eminence explants. Median eminence explants were incubated for $30 \mathrm{~min}$ in the presence or absence of the NO precursor, L-arginine (L-Arg, $500 \mathrm{~mm}$ ). Under basal unstimulated conditions (control), the GnRH axonal endings were separated from the pericapillary space (p.s.) (delineated by the parenchymatous basal lamina, white arrow). Most of the nerve endings were enwrapped by a single tanycytic end-foot (Tan.). Retraction of tanycytic processes and formation of neurovascular junctions by $\mathrm{GnRH}$ nerve terminals that directly contact the pericapillary observed in situ (white arrow) were detected upon treatment with L-Arg. Few tanycytic processes remained around GnRH nerve terminals that had direct access to the pericapillary space (black arrows, L-Arg panel). Scale bar: $1 \mu \mathrm{m}$ [from 63, 132, with permission]. 


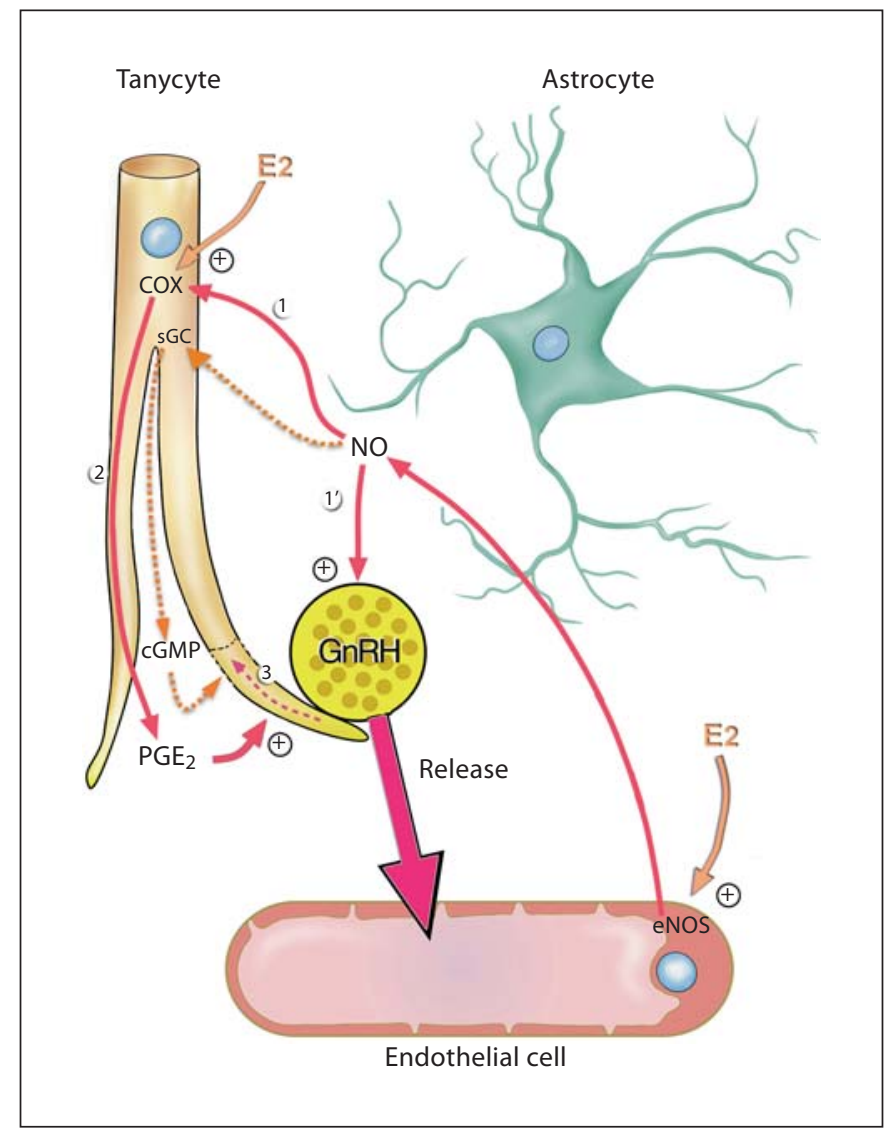

Fig. 5. Schematic representation of endothelial-glial interactions involved in the control of GnRH neurosecretion in the median eminence. Endothelial-neuronal interactions at the level of the median eminence involves the production of NO by endothelial cells of fenestrated capillaries of the portal blood vessels. Upon its secretion, NO diffuses from its source, where it not only stimulates the release of $\mathrm{GnRH}$ from the neighboring $\mathrm{GnRH}$ neuroendocrine terminals $\left(1^{\prime}\right)$ [114] but also promotes their access to the bloodstream by inducing cytoarchitectural changes in tanycytic end-feet (1-3) [63]. Downstream effectors of endothelial NO-mediated plasticity in tanycytes were shown to be both sGC and COX (1). Estrogens are likely to be the key humoral factors involved in the orchestration of the endothelia-to-glia communication that allows GnRH neurons to directly contact the pituitary portal blood vessels on the day of proestrus [132]. Estrogen treatment upregulates COX expression while leaving unchanged the expression of sGC. In addition, COX products and $\mathrm{PGE}_{2}$ in particular (2) promote acute remodeling of actin cytoskeleton in tanycytes and cause cytoplasm retraction within tanycytic processes and end-feet (3). In parallel, estrogens stimulate eNOS expression in median eminence endothelial cells. Both tanycytes and endothelial cells were shown to express ERs in vitro [132] and in vivo [133] [adapted from 9, 150, with permission].
Estradiol appears to sensitize tanycytes to NO since subeffective doses of SNP induced cell retraction in estradiol-treated single tanycyte cultures [132]. Both tanycytes and endothelial cells were shown to express ERs in vitro [132] and in vivo [133]. Estradiol, on top of promoting eNOS expression in endothelial cells $[117,132]$, also upregulates COX-1 and COX-2 expression in tanycytes, while leaving sGC expression unchanged [132]. Together with data showing that isolated tanycytes secrete $\mathrm{PGE}_{2}$ both under control and stimulated conditions [134], and that $\mathrm{PGE}_{2}$ stimulates acute cellular retraction in simple tanycyte cultures [132], these findings support the conclusion that the acute estradiol-induced tanycyte retraction mediated by endothelial NO depends mainly on the activation of COX pathways in tanycytes. Direct evidence for the ability of COX products to control neuronal-glial plasticity at the neurohemal junction was obtained from experiments in which $\mathrm{PGE}_{2}$ was applied directly to median eminence explants at concentrations known to stimulate GnRH release [135-137], and structural remodeling was observed in a matter of minutes. $\mathrm{PGE}_{2}$ treatment caused the advancement of GnRH neurosecretory terminals towards the pericapillary space, a phenomenon that probably results from the retraction of tanycyte end-feet [132]. Intriguingly, $\mathrm{PGE}_{2}$ failed to promote direct neurovascular contacts between GnRH axons and the vascular wall. This is in contrast to the aforementioned effects of L-arginine treatment, and it suggests that additional downstream signaling pathways, such as those involving cGMP, are required for NO to fully exert its effects on neuronal-glial plasticity (fig. 5). The recent demonstration of an involvement of NO-cGMP signaling in axonal elongation and/or growth cone orientation [63, 138-140] supports this interpretation.

Results obtained in adult rats in vivo corroborate the role of $\mathrm{PGE}_{2}$ in the mechanism that controls neuronalglial plasticity at the neurohemal junction for GnRH neurons. Intracerebral infusion of the same COX antagonist that blocks NO-mediated actin cytoskeleton remodeling in primary cultures (indomethacin) [63] into the median eminence resulted in a marked disruption of the ovarian cycle [132], which requires the coordinated delivery of $\mathrm{GnRH}$ into the hypothalamo-hypophyseal portal system. Animals treated with the COX inhibitor spent most of their time in either the diestrus or the estrus phase [132], when GnRH release is low [141] and GnRH neuroendocrine terminals are enclosed by tanycyte end-feet $[129,130]$. These results highlight the physiological importance of PGs in the cell-cell communication processes regulating $\mathrm{GnRH}$ release and they are in full agree- 
ment with pioneering data obtained over 25 years ago demonstrating that $\mathrm{PGE}_{2}$ synthesis increases within the hypothalamic region containing the median eminence during the onset of the first preovulatory surge at puberty [50], as well as with the findings that inhibitors of COX activities alter the onset of the steroid-induced LH surge in ovariectomized female rats [51].

Taken together, these findings provide strong evidence that endothelial NO synthesis in median eminence vascular endothelial cells is a crucial target for the action of estrogen on the structural remodeling that takes place at the projection site of $\mathrm{GnRH}$ neurons and on $\mathrm{GnRH}$ neurosecretion during the estrous cycle. Estrogen may induce endothelial cells to produce $\mathrm{NO}$ and tanycytes to make COX in the median eminence. Endothelial NO diffuses into neural tissue and acts on tanycytes to stimulate $\mathrm{PGE}_{2}$ production, which in turn acts with additional factors that remain unidentified to promote the acute retraction of tanycyte end-feet that allows GnRH nerve terminals to form direct neurohemal junctions (fig. 5).

\section{Conclusion}

As evidenced by the findings presented in this review, a fair amount of progress has been achieved in the last 20 years towards understanding the contributions and importance of $\mathrm{NO}$ in $\mathrm{GnRH}$ neuroendocrine regulation. Evidence has accumulated in the literature to support a role of $\mathrm{NO}$ at both the preoptic region and the median eminence of the hypothalamus to regulate the reproductive function. While in the preoptic region neuronal NO may serve to control the bursting activity of $\mathrm{GnRH}$ neurons, in the median eminence, endothelial NO may represent one of the synchronizing cues that coordinate $\mathrm{GnRH}$ release from neuroendocrine terminals, and thus provides a unique regulatory mechanism that may be required for appropriate delivery of GnRH to the pituitary during the estrous cycle. In turn, NO-producing enzymes and NO receptors are subjected to regulation by estrogens, thus completing the feedback loop.

Although much has been accomplished, significant gaps still remain in our knowledge. For instance, while there is good knowledge and understanding with respect to the role of NMDA-Rs in the control of nNOS activity in the preoptic region during the estrous cycle, considerably less is known concerning the regulation of eNOS activity within the median eminence. Furthermore, the interaction of NO with hypothalamic neuropeptides key to reproductive function, such as kisspeptin, requires clarification. These gaps in our knowledge will undoubtedly be closed as the field continues to move forward. While work still remains, the body of evidence accumulated to date suggests that $\mathrm{NO}$ is a chemical transmitter coordinating neuronal-glial-endothelial interactions in the hypothalamus and functions as a critical central cue coordinating GnRH neurosecretion.

\section{Acknowledgements}

This research was supported by the Institut National de la Santé et de la Recherche Médicale (Inserm, France) grant U837, the Fondation pour la Recherche Médicale (Equipe FRM), l'Agence Nationale de la Recherche (ANR), the Indo-French Centre for the Promotion of Advanced Research (IFCPAR), the Université Lille 2 and the imaging Core of IFR114. J.P. was a postdoctoral fellow supported by IFCPAR. X.A.T., C.C. and J.C. were PhD students supported by a fellowship from the Inserm and the Région Nord Pas de Calais. N.B. was a PhD student supported by a fellowship from the Région Nord Pas de Calais and the Université Lille 2. N.K.H. was a PhD student supported by Inserm grant U837. S.S. was a PhD student supported by a fellowship from the Ministère Délégué à la Recherche et aux Nouvelles Technologies.

\section{References}

1 Brann DW, Mahesh VB: Excitatory amino acids: evidence for a role in the control of reproduction and anterior pituitary hormone secretion. Endocr Rev 1997;18:678-700.

2 Herbison A: Physiology of the gonadotropinreleasing hormone neuronal network; in Neill JD (ed): Knobil and Neill's Physiology of Reproduction. Amsterdam, Elsevier, 2006, pp 1415-1482.

-3 Simerly RB: Wired for reproduction: organization and development of sexually dimorphic circuits in the mammalian forebrain. Annu Rev Neurosci 2002;25:507-536.
4 Ojeda SR, Ma YJ, Lee BJ, Prevot V: Glia-toneuron signaling and the neuroendocrine control of female puberty. Recent Prog Horm Res 2000;55:197-223.

-5 Prevot V, Bellefontaine N, Baroncini M, Sharif A, Hanchate NK, Parkash J, Campagne C, de Seranno S: GnRH nerve terminals, tanycytes and neurohaemal junction remodeling in the adult median eminence: functional consequences for reproduction and dynamic role of vascular endothelial cells. J Neuroendocrinol 2010;22:639-649.
6 Herbison AE: Multimodal influence of estrogen upon gonadotropin-releasing hormone neurons. Endocr Rev 1998;19:302330.

$\checkmark 7$ Christian CA, Moenter SM: The neurobiology of preovulatory and estradiol-induced gonadotropin-releasing hormone surges. Endocr Rev 2010;31:544-577.

-8 Garcia-Segura LM, Lorenz B, DonCarlos LL: The role of glia in the hypothalamus: implications for gonadal steroid feedback and reproductive neuroendocrine output. Reproduction 2008; 135:419-429. 
$\checkmark 9$ Prevot V, Hanchate NK, Bellefontaine N, 22 Herbison AE, Simonian SX, Norris PJ, EmSharif A, Parkash J, Estrella C, Allet C, de Seranno S, Campagne C, d'Anglemont de Tassigny X, Baroncini M: Function-related structural plasticity of the GnRH system: a role for neuronal-glial-endothelial interactions. Front Neuroendocrinol 2010;31:241258.

10 Ignarro LJ, Buga GM, Wood KS, Byrns RE, Chaudhuri G: Endothelium-derived relaxing factor produced and released from artery and vein is nitric oxide. Proc Natl Acad Sci USA 1987;84:9265-9269.

- 11 Palmer RM, Ferrige AG, Moncada S: Nitric oxide release accounts for the biological activity of endothelium-derived relaxing factor. Nature 1987;327:524-526.

12 Garthwaite J, Charles SL, Chess-Williams R: Endothelium-derived relaxing factor release on activation of NMDA receptors suggests role as intercellular messenger in the brain. Nature 1988;336:385-388.

13 Forstermann U, Schmidt HH, Pollock JS, Sheng H, Mitchell JA, Warner TD, Nakane M, Murad F: Isoforms of nitric oxide synthase. Characterization and purification from different cell types. Biochem Pharmacol 1991;42:1849-1857.

-14 Bredt DS, Snyder SH: Isolation of nitric oxide synthetase, a calmodulin-requiring enzyme. Proc Natl Acad Sci USA 1990;87:682-685.

- 15 Bredt DS, Glatt CE, Hwang PM, Fotuhi M, Dawson TM, Snyder SH: Nitric oxide synthase protein and mRNA are discretely localized in neuronal populations of the mammalian CNS together with NADPH diaphorase. Neuron 1991;7:615-624.

- 16 Bredt DS, Hwang PM, Glatt CE, Lowenstein C, Reed RR, Snyder SH: Cloned and expressed nitric oxide synthase structurally resembles cytochrome P450 reductase. Nature 1991;351:714-718.

- 17 Seidel B, Stanarius A, Wolf G: Differential expression of neuronal and endothelial nitric oxide synthase in blood vessels of the rat brain. Neurosci Lett 1997;239:109-112.

- 18 Yamada K, Emson P, Hokfelt T: Immunohistochemical mapping of nitric oxide synthase in the rat hypothalamus and colocalization with neuropeptides. J Chem Neuroanat 1996;10:295-316

-19 Stanarius A, Topel I, Schulz S, Noack H, Wolf G: Immunocytochemistry of endothelial nitric oxide synthase in the rat brain: a light and electron microscopical study using the tyramide signal amplification technique. Acta Histochem 1997;99:411-429.

-20 Dawson TM, Bredt DS, Fotuhi M, Hwang PM, Snyder SH: Nitric oxide synthase and neuronal NADPH diaphorase are identical in brain and peripheral tissues. Proc Natl Acad Sci USA 1991;88:7797-7801.

-21 Hope BT, Michael GJ, Knigge KM, Vincent SR: Neuronal NADPH diaphorase is a nitric oxide synthase. Proc Natl Acad Sci USA 1991;88:2811-2814. synthase immunoreactivity to $\mathrm{GnRH}$ neurons in the ovariectomized and intact female rat. J Neuroendocrinol 1996;8:73-82.

- 23 Edelmann M, Wolfe C, Scordalakes EM, Rissman EF, Tobet S: Neuronal nitric oxide synthase and calbindin delineate sex differences in the developing hypothalamus and preoptic area. Dev Neurobiol 2007;67:13711381.

24 Cho HJ, Xie QW, Calaycay J, Mumford RA, Swiderek KM, Lee TD, Nathan C: Calmodulin is a subunit of nitric oxide synthase from macrophages. J Exp Med 1992;176:599-604.

25 Forstermann U, Pollock JS, Schmidt HH, Heller M, Murad F: Calmodulin-dependent endothelium-derived relaxing factor/nitric oxide synthase activity is present in the particulate and cytosolic fractions of bovine aortic endothelial cells. Proc Natl Acad Sci USA 1991;88:1788-1792.

- 26 Pollock JS, Forstermann U, Mitchell JA, Warner TD, Schmidt HH, Nakane M, Murad F: Purification and characterization of particulate endothelium-derived relaxing factor synthase from cultured and native bovine aortic endothelial cells. Proc Natl Acad Sci USA 1991;88:10480-10484.

27 Kiedrowski L, Costa E, Wroblewski JT: Glutamate receptor agonists stimulate nitric oxide synthase in primary cultures of cerebellar granule cells. J Neurochem 1992;58:335341.

28 Feron O, Dessy C, Desager JP, Balligand JL: Hydroxy-methylglutaryl-coenzyme A reductase inhibition promotes endothelial nitric oxide synthase activation through a decrease in caveolin abundance. Circulation 2001;103:113-118.

29 Feron O, Belhassen L, Kobzik L, Smith TW Kelly RA, Michel T: Endothelial nitric oxide synthase targeting to caveolae. Specific interactions with caveolin isoforms in cardiac myocytes and endothelial cells. J Biol Chem 1996;271:22810-22814.

30 Michel JB, Feron O, Sacks D, Michel T: Reciprocal regulation of endothelial nitric-oxide synthase by $\mathrm{Ca}^{2+}$-calmodulin and caveolin. J Biol Chem 1997;272:15583-15586.

- 31 Fulton D, Gratton JP, McCabe TJ, Fontana J, Fujio Y, Walsh K, Franke TF, Papapetropoulos A, Sessa WC: Regulation of endotheliumderived nitric oxide production by the protein kinase Akt. Nature 1999;399:597-601.

32 Rameau GA, Tukey DS, Garcin-Hosfield ED, Titcombe RF, Misra C, Khatri L, Getzoff ED, Ziff EB: Biphasic coupling of neuronal nitric oxide synthase phosphorylation to the NMDA receptor regulates AMPA receptor trafficking and neuronal cell death. J Neurosci 2007;27:3445-3455.

33 Aarts M, Liu Y, Liu L, Besshoh S, Arundine M, Gurd JW, Wang YT, Salter MW, Tymianski M: Treatment of ischemic brain damage by perturbing NMDA receptor-PSD-95 protein interactions. Science 2002;298:846-850. son PC: Relationship of neuronal nitric oxide
34 Christopherson KS, Hillier BJ, Lim WA, Bredt DS: PSD-95 assembles a ternary complex with the N-methyl-D-aspartic acid receptor and a bivalent neuronal NO synthase PDZ domain. J Biol Chem 1999;274:2746727473.

35 Sattler R, Xiong Z, Lu WY, Hafner M, MacDonald JF, Tymianski M: Specific coupling of NMDA receptor activation to nitric oxide neurotoxicity by PSD-95 protein. Science 1999;284:1845-1848.

36 Hayashi Y, Nishio M, Naito Y, Yokokura H, Nimura Y, Hidaka H, Watanabe Y: Regulation of neuronal nitric-oxide synthase by calmodulin kinases. J Biol Chem 1999;274: 20597-20602.

37 Rameau GA, Chiu LY, Ziff EB: Bidirectional regulation of neuronal nitric-oxide synthase phosphorylation at serine 847 by the $\mathrm{N}$ methyl-D-aspartate receptor. J Biol Chem 2004;279:14307-14314.

38 Dudzinski DM, Igarashi J, Greif D, Michel T: The regulation and pharmacology of endothelial nitric oxide synthase. Annu Rev Pharmacol Toxicol 2006;46:235-276.

39 Dessy C, Feron O, Balligand JL: The regulation of endothelial nitric oxide synthase by caveolin: a paradigm validated in vivo and shared by the 'endothelium-derived hyperpolarizing factor'. Pflügers Arch 2010;459: 817-827.

40 Prast H, Philippu A: Nitric oxide as modulator of neuronal function. Prog Neurobiol 2001;64:51-68

41 Garthwaite J, Boulton CL: Nitric oxide signaling in the central nervous system. Annu Rev Physiol 1995;57:683-706.

42 Hall CN, Garthwaite J: What is the real physiological NO concentration in vivo? Nitric Oxide 2009;21:92-103.

43 Garthwaite J: Concepts of neural nitric oxide-mediated transmission. Eur J Neurosci 2008;27:2783-2802

44 Arnold WP, Mittal CK, Katsuki S, Murad F: Nitric oxide activates guanylate cyclase and increases guanosine $3^{\prime}: 5^{\prime}$-cyclic monophosphate levels in various tissue preparations. Proc Natl Acad Sci USA 1977;74:3203-3207.

-45 Knowles RG, Palacios M, Palmer RM, Moncada S: Formation of nitric oxide from $\mathrm{L}$-arginine in the central nervous system: a transduction mechanism for stimulation of the soluble guanylate cyclase. Proc Natl Acad Sci USA 1989;86:5159-5162.

46 Garthwaite J: New insight into the functioning of nitric oxide-receptive guanylyl cyclase: physiological and pharmacological implications. Mol Cell Biochem 2010;334: 221-232.

47 Rettori V, Gimeno M, Lyson K, McCann SM: Nitric oxide mediates norepinephrine-induced prostaglandin $\mathrm{E}_{2}$ release from the hypothalamus. Proc Natl Acad Sci USA 1992; 89:11543-11546. 
-48 Salvemini D, Misko TP, Masferrer JL, Seibert K, Currie MG, Needleman P: Nitric oxide activates cyclooxygenase enzymes. Proc Natl Acad Sci USA 1993;90:7240-7244.

-49 Savchenko A, Barnes S, Kramer RH: Cyclicnucleotide-gated channels mediate synaptic feedback by nitric oxide. Nature 1997;390 694-698.

50 Ojeda SR, Campbell WB: An increase in hypothalamic capacity to synthesize prostaglandin $\mathrm{E}_{2}$ precedes the first preovulatory surge of gonadotropins. Endocrinology 1982;111:1031-1037.

-51 Ojeda SR, Harms PG, McCann SM: Effect of inhibitors of prostaglandin synthesis on gonadotropin release in the rat. Endocrinology 1975; $97: 843-854$

-52 Kalra SP, Horvath T, Naftolin F, Xu B, Pu S, Kalra PS: The interactive language of the hypothalamus for the gonadotropin-releasing hormone $(\mathrm{GNRH})$ system. J Neuroendocrinol 1997;9:569-576.

53 McCann SM, Haens G, Mastronardi C, Walczewska A, Karanth S, Rettori V, Yu WH: The role of nitric oxide in control of LHRH release that mediates gonadotropin release and sexual behavior. Curr Pharm Des 2003; 9:381-390.

54 Prevot V, Bouret S, Stefano GB, Beauvillain J: Median eminence nitric oxide signaling. Brain Res Brain Res Rev 2000;34:27-41.

55 Moretto M, Lopez FJ, Negro-Vilar A: Nitric oxide regulates luteinizing hormone-releasing hormone secretion. Endocrinology 1993; 133:2399-2402.

56 Rettori V, Belova N, Dees WL, Nyberg CL, Gimeno M, McCann SM: Role of nitric oxide in the control of luteinizing hormone-releasing hormone release in vivo and in vitro. Proc Natl Acad Sci USA 1993;90:1013010134.

57 Bonavera JJ, Sahu A, Kalra PS, Kalra SP: Evidence in support of nitric oxide involvement in the cyclic release of prolactin and LH surges. Brain Res 1994;660:175-179.

$58 \mathrm{Pu}$ S, Kalra PS, Kalra SP: Ovarian steroidindependent diurnal rhythm in cyclic GMP/ nitric oxide efflux in the medial preoptic area: possible role in preovulatory and ovarian steroid-induced LH surge. J Neuroendocrinol 1998;10:617-625.

$59 \mathrm{Pu}$ S, Xu B, Kalra SP, Kalra PS: Evidence that gonadal steroids modulate nitric oxide efflux in the medial preoptic area: effects of $\mathrm{N}$ methyl-D-aspartate and correlation with luteinizing hormone secretion. Endocrinology 1996;137:1949-1955.

-60 Aguan K, Mahesh VB, Ping L, Bhat G, Brann DW: Evidence for a physiological role for nitric oxide in the regulation of the LH surge: effect of central administration of antisense oligonucleotides to nitric oxide synthase. Neuroendocrinology 1996;64:449-455.
61 Bonavera JJ, Sahu A, Kalra PS, Kalra SP: Evidence that nitric oxide may mediate the ovarian steroid-induced luteinizing hormone surge: involvement of excitatory amino acids. Endocrinology 1993;133:24812487.

62 d'Anglemont de Tassigny X, Campagne C, Dehouck B, Leroy D, Holstein GR, Beauvillain JC, Buee-Scherrer V, Prevot V: Coupling of neuronal nitric oxide synthase to NMDA receptors via postsynaptic density-95 depends on estrogen and contributes to the central control of adult female reproduction. J Neurosci 2007;27:6103-6114.

63 De Seranno S, Estrella C, Loyens A, Cornea A, Ojeda SR, Beauvillain JC, Prevot V: Vascular endothelial cells promote acute plasticity in ependymoglial cells of the neuroendocrine brain. J Neurosci 2004;24:1035310363.

64 Huang PL, Dawson TM, Bredt DS, Snyder SH, Fishman MC: Targeted disruption of the neuronal nitric oxide synthase gene. Cell 1993; 75:1273-1286.

65 Gyurko R, Leupen S, Huang PL: Deletion of exon 6 of the neuronal nitric oxide synthase gene in mice results in hypogonadism and infertility. Endocrinology 2002;143:27672774.

66 Sortino MA, Aleppo G, Scapagnini U, Canonico PL: Involvement of nitric oxide in the regulation of gonadotropin-releasing hormone release from the GT1-1 neuronal cell line. Endocrinology 1994;134:1782-1787.

67 Lopez FJ, Moretto M, Merchenthaler I, Negro-Vilar A: Nitric oxide is involved in the genesis of pulsatile LHRH secretion from immortalized LHRH neurons. J Neuroendocrinol 1997;9:647-654.

68 Westel WC: Immortalized hypothalamic luteinizing hormone-releasing hormone (LHRH) neurons: a new tool for dissecting the molecular an cellular basis of LHRH physiology. Cell Moll Neurobiol 1995; 15:4378.

69 Mahachoklertwattana P, Black SM, Kaplan SL, Bristow JD, Grumbach MM: Nitric oxide synthesized by gonadotropin-releasing hormone neurons is a mediator of N-methyl-Daspartate-induced GnRH secretion. Endocrinology 1994;135:1709-1712.

70 Belsham DD, Mellon PL: Transcription factors Oct- 1 and C/EBP $\beta$ (CCAAT/enhancerbinding protein- $\beta$ ) are involved in the glutamate/nitric oxide/cyclic-guanosine 5'monophosphate-mediated repression of mediated repression of gonadotropin-releasing hormone gene expression. Mol Endocrinol 2000;14:212-228.

71 Bhat GK, Mahesh VB, Lamar CA, Ping L, Aguan K, Brann DW: Histochemical localization of nitric oxide neurons in the hypothalamus: association with gonadotropinreleasing hormone neurons and co-localization with $\mathrm{N}$-methyl-D-aspartate receptors. Neuroendocrinology 1995;62:187-197.
72 Grossman AB, Rossmanith WG, Kabigting EB, Cadd G, Clifton D, Steiner RA: The distribution of hypothalamic nitric oxide synthase mRNA in relation to gonadotrophinreleasing hormone neurons. J Endocrinol 1994;140:R5-R8.

73 Clasadonte J, Poulain P, Beauvillain JC, Prevot V: Activation of neuronal nitric oxide release inhibits spontaneous firing in adult gonadotropin-releasing hormone neurons: a possible local synchronizing signal. Endocrinology 2008; 149:587-596.

74 Suter KJ, Song WJ, Sampson TL, Wuarin JP, Saunders JT, Dudek FE, Moenter SM: Genetic targeting of green fluorescent protein to gonadotropin-releasing hormone neurons: characterization of whole-cell electrophysiological properties and morphology. Endocrinology 2000;141:412-419.

-75 Spergel DJ, Kruth U, Hanley DF, Sprengel R, Seeburg PH: GABA- and glutamate-activated channels in green fluorescent proteintagged gonadotropin-releasing hormone neurons in transgenic mice. J Neurosci 1999; 19:2037-2050.

76 Han SK, Todman MG, Herbison AE: Endogenous GABA release inhibits the firing of adult gonadotropin-releasing hormone neurons. Endocrinology 2004;145:495-499.

77 Hah JM, Roman LJ, Martasek P, Silverman RB: Reduced amide bond peptidomimetics. (4S)-N-(4-amino-5-[aminoakyl]aminopentyl)- $\mathrm{N}^{\prime}$-nitroguanidines, potent and highly selective inhibitors of neuronal nitric oxide synthase. J Med Chem 2001;44:26672670.

78 Moenter SM, Caraty A, Locatelli A, Karsch FJ: Pattern of gonadotropin-releasing hormone $(\mathrm{GnRH})$ secretion leading up to ovulation in the ewe: existence of a preovulatory GnRH surge. Endocrinology 1991;129:11751182.

79 Sarkar DK, Chiappa SA, Fink G, Sherwood NM: Gonadotropin-releasing hormone surge in pro-oestrous rats. Nature 1976;264: 461-463.

80 Sarkar DK, Minami S: Diurnal variation in luteinizing hormone-releasing hormone and $\beta$-endorphin release in pituitary portal plasma during the rat estrous cycle. Biol Reprod 1995;53:38-45.

81 Lamar CA, Bhat GK, Mahesh VB, Brann DW: Evidence that neuronal nitric oxide synthase but not heme oxygenase increases in the hypothalamus on proestrus afternoon. Neuroendocrinology 1999;70:360367.

82 Okamura H, Yokosuka M, Hayashi S: Estrogenic induction of NADPH-diaphorase activity in the preoptic neurons containing estrogen receptor immunoreactivity in the female rat. J Neuroendocrinol 1994;6:597-601. 
83 Rachman IM, Unnerstall JR, Pfaff DW, Cohen RS: Regulation of neuronal nitric oxide synthase mRNA in lordosis-relevant neurons of the ventromedial hypothalamus following short-term estrogen treatment. Brain Res Mol Brain Res 1998;59:105-108.

-84 Sica M, Martini M, Viglietti-Panzica C, Panzica G: Estrous cycle influences the expression of neuronal nitric oxide synthase in the hypothalamus and limbic system of female mice. BMC Neurosci 2009; 10:78.

85 Parkash J, d'Anglemont de Tassigny X, Bellefontaine N, Campagne C, Mazure D, BueeScherrer V, Prevot V: Phosphorylation of Nmethyl-D-aspartic acid receptor-associated neuronal nitric oxide synthase depends on estrogens and modulates hypothalamic nitric oxide production during the ovarian cycle. Endocrinology 2010;151:2723-2735.

-86 d'Anglemont de Tassigny X, Campagne C, Steculorum S, Prevot V: Estradiol induces physical association of neuronal nitric oxide synthase with NMDA receptor and promotes nitric oxide formation via estrogen receptor activation in primary neuronal cultures. J Neurochem 2009;109:214-224.

- 87 Sato S, Braham CS, Putnam SK, Hull EM: Neuronal nitric oxide synthase and gonadal steroid interaction in the MPOA of male rats: co-localization and testosterone-induced restoration of copulation and nNOS immunoreactivity. Brain Res 2005;1043:205-213.

-88 Scordalakes EM, Shetty SJ, Rissman EF: Roles of estrogen receptor $\alpha$ and androgen receptor in the regulation of neuronal nitric oxide synthase. J Comp Neurol 2002;453: 336-344.

89 Chakraborty TR, Ng L, Gore AC: Colocalization and hormone regulation of estrogen receptor $\alpha$ and N-methyl-D-aspartate receptor in the hypothalamus of female rats. Endocrinology 2003;144:299-305.

90 Blaustein JD: Cytoplasmic estrogen receptors in rat brain: immunocytochemical evidence using three antibodies with distinct epitopes. Endocrinology 1992;131:13361342.

\$1 Blaustein JD, Lehman MN, Turcotte JC, Greene G: Estrogen receptors in dendrites and axon terminals in the guinea pig hypothalamus. Endocrinology 1992;131:281-290.

-92 Donato J Jr, Frazao R, Fukuda M, Vianna CR, Elias CF: Leptin induces phosphorylation of neuronal nitric oxide synthase in defined hypothalamic neurons. Endocrinology 2010; 151:5415-5427.

93 Gingerich S, Krukoff TL: Activation of ER $\beta$ increases levels of phosphorylated nNOS and NO production through a Src/PI3K/Akt-dependent pathway in hypothalamic neurons. Neuropharmacology 2008;55:878-885.

$\checkmark 94$ Brann DW, Mahesh VB: Endogenous excitatory amino acid involvement in the preovulatory and steroid-induced surge of gonadotropins in the female rat. Endocrinology 1991;128:1541-1547.
$\$ 95$ Urbanski HF, Ojeda SR: A role for N-methyl-D-aspartate receptors in the control of LH secretion and initiation of female puberty. Endocrinology 1990;126:1774-1776.

-96 Wintermantel TM, Campbell RE, Porteous R, Bock D, Grone HJ, Todman MG, Korach KS, Greiner E, Perez CA, Schutz G, Herbison $\mathrm{AE}$ : Definition of estrogen receptor pathway critical for estrogen positive feedback to gonadotropin-releasing hormone neurons and fertility. Neuron 2006;52:271-280.

97 Herbison AE: Estrogen positive feedback to gonadotropin-releasing hormone neurons in the rodent: the case for the rostral periventricular area of the third ventricle. Brain Res Rev 2008;57:277-287.

-98 Clarkson J, Herbison AE: Oestrogen, kisspeptin, GPR54 and the pre-ovulatory luteinising hormone surge. J Neuroendocrinol 2009;21:305-311.

-99 d'Anglemont de Tassigny X, Colledge WH: The role of kisspeptin signaling in reproduction. Physiology (Bethesda) 2010;25: 207-217.

100 Oakley AE, Clifton DK, Steiner RA: Kisspeptin signaling in the brain. Endocr Rev 2009;30:713-743.

101 d'Anglemont de Tassigny X, Fagg LA, Dixon JP, Day K, Leitch HG, Hendrick AG, Zahn D, Franceschini I, Caraty A, Carlton MB, Aparicio SA, Colledge WH: Hypogonadotropic hypogonadism in mice lacking a functional Kiss1 gene. Proc Natl Acad Sci USA 2007;104:10714-10719.

102 De Roux N, Genin E, Carel JC, Matsuda F, Chaussain JL, Milgrom E: Hypogonadotropic hypogonadism due to loss of function of the KiSS1-derived peptide receptor GPR54. Proc Natl Acad Sci USA 2003;100: 10972-10976.

103 Seminara SB, Messager S, Chatzidaki EE, Thresher RR, Acierno JS Jr, Shagoury JK, Bo-Abbas Y, Kuohung W, Schwinof KM, Hendrick AG, Zahn D, Dixon J, Kaiser UB, Slaugenhaupt SA, Gusella JF, O'Rahilly S, Carlton MB, Crowley WF Jr, Aparicio SA, Colledge WH: The GPR54 gene as a regulator of puberty. N Engl J Med 2003;349: 1614-1627.

104 Messager S, Chatzidaki EE, Ma D, Hendrick AG, Zahn D, Dixon J, Thresher RR, Malinge I, Lomet D, Carlton MB, Colledge WH, Caraty A, Aparicio SA: Kisspeptin directly stimulates gonadotropin-releasing hormone release via $\mathrm{G}$ protein-coupled receptor 54. Proc Natl Acad Sci USA 2005; 102:1761-1766.

105 Lapatto R, Pallais JC, Zhang D, Chan YM, Mahan A, Cerrato F, Le WW, Hoffman GE, Seminara SB: Kiss1-/- mice exhibit more variable hypogonadism than Gpr54-/mice. Endocrinology 2007;148:4927-4936.
106 d'Anglemont de Tassigny X, Ackroyd KJ, Chatzidaki EE, Colledge WH: Kisspeptin signaling is required for peripheral but not central stimulation of gonadotropin-releasing hormone neurons by NMDA. J Neurosci 2010;30:8581-8590.

107 Bellefontaine N, Hanchate NK, Leroy D, Colledge WH, d'Anglemont de Tassigny X, Prevot V: Morphological evidence for the interrelationship of kisspeptin and nitric oxide containing neurons in the $\mathrm{GnRH}$ neuronal network. 7th International Congress of Neuroendocrinology, Rouen, 2010, p 81.

108 Pielecka-Fortuna J, Chu Z, Moenter SM: Kisspeptin acts directly and indirectly to increase gonadotropin-releasing hormone neuron activity and its effects are modulated by estradiol. Endocrinology 2008; 149: 1979-1986.

109 Pielecka-Fortuna J, Moenter SM: Kisspeptin increases $\gamma$-aminobutyric acidergic and glutamatergic transmission directly to gonadotropin-releasing hormone neurons in an estradiol-dependent manner. Endocrinology 2010;151:291-300.

110 Neal-Perry G, Lebesgue D, Lederman M, Shu J, Zeevalk GD, Etgen AM: The excitatory peptide kisspeptin restores the luteinizing hormone surge and modulates amino acid neurotransmission in the medial preoptic area of middle-aged rats. Endocrinology 2009;150:3699-3708.

111 Ojeda SR, Lomniczi A, Sandau US: Glialgonadotrophin hormone $(\mathrm{GnRH})$ neurone interactions in the median eminence and the control of GnRH secretion. J Neuroendocrinol 2008;20:732-742.

112 Hrabovszky E, Liposits Z: Novel aspects of glutamatergic signalling in the neuroendocrine system. J Neuroendocrinol 2008;20: 743-751.

113 Ceccatelli S, Lundberg JM, Fahrenkrug J, Bredt DS, Snyder SH, Hokfelt T: Evidence for involvement of nitric oxide in the regulation of hypothalamic portal blood flow. Neuroscience 1992;51:769-772.

114 Knauf C, Prevot V, Stefano GB, Mortreux G, Beauvillain JC, Croix D: Evidence for a spontaneous nitric oxide release from the rat median eminence: influence on gonadotropin-releasing hormone release. Endocrinology 2001;142:2343-2350.

115 Bourguignon JP, Gerard A, Varez Gonzalez ML, Franchimont P: Control of pulsatile secretion of gonadotrophin-releasing hormone from hypothalamic explants. Hum Reprod 1993;8(suppl 2):18-22.

116 Rasmussen DD: Episodic gonadotropin-releasing hormone release from the rat isolated median eminence in vitro. Neuroendocrinology 1993;58:511-518. 
-117 Knauf C, Ferreira S, Hamdane M, Mailliot C, Prevot V, Beauvillain JC, Croix D: Variation of endothelial nitric oxide synthase synthesis in the median eminence during the rat estrous cycle: an additional argument for the implication of vascular blood vessel in the control of GnRH release. Endocrinology 2001;142:4288-4294.

-118 Gingerich S, Krukoff TL: Estrogen modulates endothelial and neuronal nitric oxide synthase expression via an estrogen receptor $\beta$-dependent mechanism in hypothalamic slice cultures. Endocrinology 2005; 146:2933-2941.

- 119 Feron O, Saldana F, Michel JB, Michel T: The endothelial nitric-oxide synthase-caveolin regulatory cycle. J Biol Chem 1998; 273:3125-3128.

- 120 Michel JB, Feron O, Sase K, Prabhakar P, Michel T: Caveolin versus calmodulin. Counterbalancing allosteric modulators of endothelial nitric oxide synthase. J Biol Chem 1997;272:25907-25912.

$\checkmark 121$ Prevot V, Croix D, Rialas CM, Poulain P, Fricchione GL, Stefano GB, Beauvillain JC: Estradiol coupling to endothelial nitric oxide stimulates gonadotropin-releasing hormone release from rat median eminence via a membrane receptor. Endocrinology 1999; 140:652-659.

122 Stefano GB, Prevot V, Beauvillain JC, Cadet P, Fimiani C, Welters I, Fricchione GL, Breton C, Lassalle P, Salzet M, Bilfinger TV: Cell-surface estrogen receptors mediate calcium-dependent nitric oxide release in human endothelia. Circulation 2000;101: 1594-1597.

123 Mullier A, Bouret SG, Prevot V, Dehouck B: Differential distribution of tight junction proteins suggests a role for tanycytes in blood-hypothalamus barrier regulation in the adult mouse brain. J Comp Neurol 2010; 518:943-962.

124 Page RB: The anatomy of the hypothalamohypophysial complex; in Knobil E, Neill JD (eds): The Physiology of Reproduction. New York, Raven Press, 1994, vol 1, pp 1527-1619.

125 King JC, Letourneau RJ: Luteinizing hormone-releasing hormone terminals in the median eminence of rats undergo dramatic changes after gonadectomy, as revealed by electron microscopic image analysis. Endocrinology 1994;134:1340-1351.

-126 Kozlowski GP, Coates PW: Ependymoneuronal specializations between LHRH fibers and cells of the cerebroventricular system. Cell Tissue Res 1985;242:301-311.

127 Meister B, Hokfelt T, Tsuruo Y, Hemmings $\mathrm{H}$, Ouimet C, Greengard P, Goldstein M: DARPP-32, a dopamine- and cyclic AMPregulated phosphoprotein in tanycytes of the mediobasal hypothalamus: distribution and relation to dopamine and luteinizing hormone-releasing hormone neurons and other glial elements. Neuroscience 1988;27:607-622.
128 Ugrumov M, Hisano S, Daikoku S: Topographic relations between tyrosine hydroxylase- and luteinizing hormone-releasing hormone-immunoreactive fibers in the median eminence of adult rats. Neurosci Lett 1989;102:159-164.

129 Prevot V, Croix D, Bouret S, Dutoit S, Tramu G, Stefano GB, Beauvillain JC: Definitive evidence for the existence of morphological plasticity in the external zone of the median eminence during the rat estrous cycle: implication of neuro-glio-endothelial interactions in gonadotropin-releasing hormone release. Neuroscience 1999;94: 809-819.

130 Prevot V, Dutoit S, Croix D, Tramu G, Beauvillain JC: Semi-quantitative ultrastructural analysis of the localization and neuropeptide content of gonadotropin-releasing hormone nerve terminals in the median eminence throughout the estrous cycle of the rat. Neuroscience 1998;84:177-191.

-131 Yamamura T, Hirunagi K, Ebihara S, Yoshimura T: Seasonal morphological changes in the neuro-glial interaction between gonadotropin-releasing hormone nerve terminals and glial end-feet in Japanese quail. Endocrinology 2004;145:4264-4267.

132 De Seranno S, d'Anglemont de Tassigny X, Estrella C, Loyens A, Kasparov S, Leroy D, Ojeda SR, Beauvillain JC, Prevot V: Role of estradiol in the dynamic control of tanycyte plasticity mediated by vascular endothelial cells in the median eminence. Endocrinology 2010;151:1760-1772.

133 Langub MC Jr, Watson RE Jr: Estrogen receptor-immunoreactive glia, endothelia, and ependyma in guinea pig preoptic area and median eminence: electron microscopy. Endocrinology 1992;130:364-372.

134 Prevot V, Cornea A, Mungenast A, Smiley G, Ojeda SR: Activation of erbB-1 signaling in tanycytes of the median eminence stimulates transforming growth factor- $\beta_{1}$ release via prostaglandin $E_{2}$ production and induces cell plasticity. J Neurosci 2003;23: 10622-10632.

135 Ojeda SR, Negro-Vilar A: Prostaglandin $\mathrm{E}_{2}$-induced luteinizing hormone-releasing hormone release involves mobilization of intracellular $\mathrm{Ca}^{2+}$. Endocrinology 1985; 116:1763-1770.

136 Ojeda SR, Urbanski HF, Costa ME, Hill DF, Moholt-Siebert M: Involvement of transforming growth factor- $\alpha$ in the release of luteinizing hormone-releasing hormone from the developing female hypothalamus. Proc Natl Acad Sci USA 1990;87:96989702.

137 Prevot V, Rio C, Cho GJ, Lomniczi A, Heger S, Neville CM, Rosenthal NA, Ojeda SR, Corfas G: Normal female sexual development requires neuregulin-erbB receptor signaling in hypothalamic astrocytes. J Neurosci 2003;23:230-239.
138 Nishiyama M, Hoshino A, Tsai L, Henley JR, Goshima Y, Tessier-Lavigne M, Poo MM, Hong K: Cyclic AMP/GMP-dependent modulation of $\mathrm{Ca}^{2+}$ channels sets the polarity of nerve growth-cone turning. $\mathrm{Na}$ ture 2003;424:990-995.

139 Seidel C, Bicker G: Nitric oxide and cGMP influence axonogenesis of antennal pioneer neurons. Development 2000;127:4541-4549.

140 Song H, Ming G, He Z, Lehmann M, McKerracher L, Tessier-Lavigne M, Poo M: Conversion of neuronal growth cone responses from repulsion to attraction by cyclic nucleotides. Science 1998;281:1515-1518.

141 Levine JE, Ramirez VD: Luteinizing hormone-releasing hormone release during the rat estrous cycle and after ovariectomy, as estimated with push-pull cannulae. Endocrinology 1982;111:1439-1448.

- 142 Komeima K, Hayashi Y, Naito Y, Watanabe Y: Inhibition of neuronal nitric-oxide synthase by calcium/calmodulin-dependent protein kinase II $\alpha$ through Ser847 phosphorylation in NG108-15 neuronal cells. J Biol Chem 2000;275:28139-28143.

143 Song T, Hatano N, Horii M, Tokumitsu H, Yamaguchi F, Tokuda M, Watanabe Y: Calcium/calmodulin-dependent protein kinase I inhibits neuronal nitric-oxide synthase activity through serine 741 phosphorylation. FEBS Lett 2004;570:133-137.

144 Adak S, Santolini J, Tikunova S, Wang Q, Johnson JD, Stuehr DJ: Neuronal nitric-oxide synthase mutant (Ser1412 $\rightarrow$ Asp) demonstrates surprising connections between heme reduction, $\mathrm{NO}$ complex formation, and catalysis. J Biol Chem 2001;276:1244-1252.

145 Akama KT, McEwen BS: Estrogen stimulates postsynaptic density-95 rapid protein synthesis via the Akt/protein kinase B pathway. J Neurosci 2003;23:2333-2339.

$>146$ Li C, Brake WG, Romeo RD, Dunlop JC, Gordon M, Buzescu R, Magarinos AM, Allen PB, Greengard P, Luine V, McEwen BS: Estrogen alters hippocampal dendritic spine shape and enhances synaptic protein immunoreactivity and spatial memory in female mice. Proc Natl Acad Sci USA 2004; 101:2185-2190.

147 Haraguchi K, Satoh K, Yanai H, Hamada F, Kawabuchi M, Akiyama T: The hDLG-associated protein DAP interacts with dynein light chain and neuronal nitric oxide synthase. Genes Cells 2000;5:905-911.

148 Hering $\mathrm{H}$, Sheng M: Dendritic spines: structure, dynamics and regulation. Nat Rev Neurosci 2001;2:880-888.

149 Kantor DB, Lanzrein M, Stary SJ, Sandoval GM, Smith WB, Sullivan BM, Davidson N, Schuman EM: A role for endothelial NO synthase in LTP revealed by adenovirusmediated inhibition and rescue. Science 1996;274:1744-1748.

150 Prevot V: Glial-neuronal-endothelial interactions are involved in the control of $\mathrm{GnRH}$ secretion. J Neuroendocrinol 2002;14:247255. 